Difficulty continued to be experienced in meeting the demands for certain types of skilled workers, notably in the building trade, engineering trade and in hotel employees and domestic servants. Reference is made in the report to the popularity of the physical training classes for the unemployed as well as to an increase in the number of areas affected by a shortage of juvenile labour, particularly in the age group 14-15. In many districts the shortage was due not only to lack of supply but also to the reluctance of parents to allow their children to take certain types of employment. Attempts made by employers to overcome the shortage included the employment of older juveniles, substitution of girls and young adults for boys and the creation of new opportunities for boys to be absorbed into the adult branches of trades. Although some trades in which apprenticeship is a common method of recruitment showed an increase in num. bers, notably engineering and shipbuilding, there was no sign of a general revival of the system of apprentice. ship.

\section{Science and the Soviet Fisheries}

THE progress of the Soviet fishing industry and the part played therein by science are graphically illustrated at an exhibition opened in the new building of the All-Union Institute of Sea Fisheries and Oceanography in Moscow. Various exhibits show the means by which the catch of sea fish has been almost doubled in recent years, reaching $1,650,000$ tons in 1937. A big modern fishing industry, equipped with up-to-date canneries, cold-storage facilities, refrigerator vessels and a fleet of trawlers, has been built up in the last twenty years. The production of tinned and frozen fish during the first and second five-year plans has been trebled, while the output of smoked fish is twenty-three times its former figure. An important feature in the development of the Soviet fishing industry is its extension to new regions. Before the Revolution, the Caspian and Azov Seas were the main fishing centres. To-day, an extensive fishing industry has been built up in the Far East and in the White and Barents Seas. The Far East has 41 canneries, with an annual output capacity of 150 million tins, as well as large floating crab canneries and a whaling fleet. The growth of the fishing industry in the White Sea is illustrated by the fact that the catch in the Murmansk Region last year was nearly 280,000 tons, as compared with 13,000 tons in 1913 .

THE development of the Soviet fishing industry has called forth a corresponding development of scientific research in this field. Before the Revolution, there were only three scientific stations to serve the industry. To-day, scores of scientific institutes, stations and laboratories are studying problems relating to fishing. The All-Union Institute of Sea Fisheries and Oceanography, which directs all the scientific work in this field, is an institution the annual budget of which runs into 16 million roubles. Special interest is attached to a section of the exhibition showing the work of Soviet men of science beneath the surface of the sea. For two years, scientists, descending to the bottom in divers' suits, have been studying the delta of the Volga, the northern part of the Caspian and of the Sea of Azov, determin. ing the location of schools of fish and their movement and observing the working of the nets. A bathysphere for the study of sea bottoms at great depths, a model of which is on display, is now under construction. Soviet men of science are introducing new methods in the processing of fish. The time required for salting has been reduced from two days to just a few seconds by the introduction of a method whereby brine is injected into the fish.

\section{Phenology of 1937}

THE Royal Meteorological Society has produced its annual phenological report at a welcomed early time this year, and Major H. C. Gunton, who is responsible, for the first time, for it, has not only made this issue to observers in April (which enables a convenient comparison with the following year upon which observations are beginning) but also considerably improved and altered the arrangement of the mass of details in the report, a number of very detailed and somewhat complicated graphs producing a better comparison between meteorological events and plant, insect and bird records than was hitherto possible without considerable detailed study. The records of the report chiefly show the lateness of wild-life in the colder and early-wetter and later drier-thanusual weather of 1937. The sudden departure of swifts in early August is of importance, for whatever the reason, it was true that the majority of swifts left the country during a rise in temperature, and the same thing happened in the last drought year; they left before the hottest day of the first heat-wave in early August. Because of the mildness, seed and berry-eating bird winter visitors, like redwings and fieldfares, were few early in the winter; the March cold caused an influx of waxwings in the north and siskins in the south. After a south-west gale, a wave of incoming migrants was noted on May 23, and on the whole, summer migrants left early.

\section{Royal Meteorological Society: Phenological Studies}

THE Royal Meteorological Society has circulated its 500 odd phenological observers in the British Isles a description of a new organization for phenologicalecological research, so that the observations will have an increased specialized value for the various subjects undertaken. The organization consists of the Royal Meteorological Society, Royal Entomological Society, British Ecological Society, South-Eastern Union of Scientific Societies, the Natural History Museum, Ministry of Agriculture and Fisheries, Bureau of Animal Population, Rothamsted Experimental Station, Society for British Entomology, British Ornithologists' Union and the British Trust for Ornithology. An executive committee will have power to co-opt additional specialists and set up panels to deal with separate branches of observational work, as migration, etc. It is hoped to explore locally as well as nationally the possibility of further collaboration of botanist, ornithologist and entomo. 